\title{
Plasma concentrations of clonazepam after single rectal administration
}

\author{
G W RYLANCE, J POULTON, R C CHERRY, AND R E CULLEN \\ Children's Hospital, Birmingham
}

SUMMARY Clonazepam was administered rectally to six children aged 1.4 to 4.7 years in a dose of $0.05 \mathrm{mg} / \mathrm{kg}$ and to five children aged 1.4 to 4.1 years in a dose of $0.1 \mathrm{mg} / \mathrm{kg}$. Plasma concentrations indicate that it is rapidly absorbed, and it may therefore be an alternative to rectal administration of diazepam in continuing convulsions.

Diazepam is considered to be the drug of choice for continuing convulsions. ${ }^{1}$ Used rectally, it is a safe and rapidly effective treatment that can be administered easily and conveniently by paediatric residents, general practitioners, nurses, and parents. ${ }^{12}$ It may, however, cause respiratory depression, ${ }^{3}$ and convulsions sometimes recur after initial suppression. $^{34}$

Intravenously administered clonazepam is effective in all forms of continuing convulsions ${ }^{5}{ }^{6}$ and has a longer duration of action than diazepam. ${ }^{6}$ Respiratory depression seems to occur much less commonly than with diazepam. Blood concentrations after rectal administration in adults are similar to those achieved after intravenous administration, ${ }^{7}$ but the rate and extent of absorption of rectally administered clonazepam in children is not known.

We have determined the plasma concentration time profiles after rectal administration of two different doses.

\section{Methods}

Eleven children (nine boys and two girls) were $\stackrel{\infty}{\circ}$ included in the study. Their ages ranged from 1.4 to 4.7 years (Table). They were all in good general health but had previously had convulsions associated with fever. One child was taking sodium valproate and another carbamazepine regularly. The test doses were given to confirm adequacy of absorption and suitability for individual home use. Ethical approval from the local district research ethical committee had been obtained.

The commercial appropriately diluted intravenous preparation Rivotril (Roche, UK) was administered directly into the rectum through $1 \mathrm{ml}$

Table Plasma clonazepam concentration in 11 children after single rectal dose administration (ng/ml)

\begin{tabular}{|c|c|c|c|c|c|c|c|c|c|c|c|c|c|c|}
\hline \multirow[t]{3}{*}{ Case no } & \multirow{3}{*}{$\begin{array}{l}\text { Age } \\
(y r s)\end{array}$} & \multirow{3}{*}{$\begin{array}{l}\text { Other } \\
\text { drugs }\end{array}$} & \multirow{3}{*}{$\begin{array}{l}\text { Dose } \\
(m g / k g)\end{array}$} & \multicolumn{11}{|c|}{ Time after administration } \\
\hline & & & & \multicolumn{7}{|c|}{ Minutes } & \multicolumn{4}{|c|}{ Hours } \\
\hline & & & & 0 & 2 & 4 & 7 & 10 & 20 & 30 & I & 2 & 4 & 12 \\
\hline 1 & $4 \cdot 6$ & & 0.044 & - & $\ldots$ & - & - & - & - & $\ldots$ & $\ldots$ & - & - & - \\
\hline 2 & $4 \cdot 7$ & & $0 \cdot(046$ & - & - & - & - & - & $2 \cdot 8$ & - & - & - & - & - \\
\hline 3 & $4 \cdot 6$ & & 0.050 & - & - & - & $1 \cdot 0$ & - & $1 \cdot 1$ & $2 \cdot 1$ & $1 \cdot 4$ & $1 \cdot 7$ & $1 \cdot 3$ & - \\
\hline 4 & 1.4 & & 0.050 & - & - & - & - & - & $5 \cdot 7$ & $7 \cdot 5$ & $11 \cdot 0$ & $7 \cdot 4$ & $10 \cdot 4$ & - \\
\hline 5 & $2 \cdot 3$ & Carbamazepine & $0 \cdot 040$ & - & - & - & - & 8.5 & $8 \cdot 2$ & $12 \cdot 0$ & $8 \cdot 5$ & $9 \cdot 5$ & 4.7 & - \\
\hline 6 & 1.4 & & 0.050 & - & $\ldots$ & - & $3 \cdot 4$ & $4 \cdot 5$ & 10.7 & $11 \cdot 5$ & $7 \cdot 2$ & $7 \cdot 2$ & 5.8 & $3 \cdot 2$ \\
\hline 7 & $2 \cdot 0$ & & 0.091 & - & - & - & $7 \cdot 1$ & $28 \cdot 0$ & $23 \cdot 3$ & $11 \cdot 7$ & $10 \cdot 5$ & $12 \cdot 3$ & $7 \cdot 3$ & $5 \cdot 3$ \\
\hline 8 & $3 \cdot 3$ & & 0.099 & - & - & - & $7 \cdot 1$ & $85 \cdot 8^{*}$ & 38.6 & $27 \cdot 1$ & $40 \cdot 5$ & $23 \cdot 7$ & $24 \cdot 3$ & $18 \cdot 7$ \\
\hline 9 & $1 \cdot 4$ & & 0.095 & - & - & - & $5 \cdot()$ & $11 \cdot 1$ & 17.9 & $18 \cdot 4$ & $17 \cdot 5$ & $12 \cdot 3$ & $13 \cdot 4$ & $8 \cdot()$ \\
\hline 10 & $3 \cdot 1$ & Sodium valproate & 0.100 & - & - & - & - & $11 \cdot 2$ & 18.8 & $25 \cdot 0$ & $23 \cdot 4$ & $21 \cdot 7$ & $20 \cdot 1$ & 11.8 \\
\hline 11 & $4 \cdot 1$ & & 0.100 & - & - & - & $7 \cdot 3$ & $13 \cdot 2$ & $24 \cdot 9$ & $26 \cdot 6$ & $37 \cdot 6$ & $39 \cdot 0$ & $18 \cdot 3$ & $20 \cdot 2$ \\
\hline
\end{tabular}

- = Undetectable concentration.

${ }^{*}$ Disproportionately high concentration omitted from peak results and Figure. 
syringes inserted $3 \mathrm{~cm}$ through the anal sphincter. Six children were given $0.05 \mathrm{mg} / \mathrm{kg}$, and five children were given $0.1 \mathrm{mg} / \mathrm{kg}$ as bolus injections. Venous blood samples were obtained through an indwelling heparinised cannula before and at two, four, seven, 10, 20, and 30 minutes and one, two, four, and 12 hours after administration.

The clonazepam concentrations in children given $0.5 \mathrm{mg} / \mathrm{kg}$ doses were measured by a modification of the method using gas chromatography with electron capture detection reported by de Silva and Bekersley. ${ }^{8}$ The overall precision of these measurements was $\pm 14.3 \%$, and concentrations of $1 \mathrm{ng} / \mathrm{ml}$ could be determined with a coefficient variation of $\pm 28 \%$. The concentrations in children given $0 \cdot 1$ $\mathrm{mg} / \mathrm{kg}$ were measured by the capillary gas chromatography method reported by de Boer et al. ${ }^{9}$ The coefficient of variation of this assay was $\pm 15 \%$.

\section{Results}

The Table shows the clonazepam concentrations for each dose. One child (case 1) in the group given 0.05 $\mathrm{mg} / \mathrm{kg}$ did not achieve detectable concentrations. Two others (cases 2 and 3 ) failed to achieve concentrations above the lower limit for detection in the group given $0 \cdot 1 \mathrm{mg} / \mathrm{kg}$. The 10 minute concentration in case 8 was disproportionately high and out of line with the remaining profile. It has been omitted from the following results. Peak concentrations in children given $0.05 \mathrm{mg} / \mathrm{kg}$ ranged from 2.8 to $12 \cdot 0 \mathrm{ng} / \mathrm{ml}$ and occurred $20-60$ minutes after rectal administration. Peaks of $18 \cdot 4-40.5 \mathrm{ng} / \mathrm{ml}$ occurred between 10 minutes and two hours in those given $0 \cdot 1$ $\mathrm{mg} / \mathrm{kg}$. No child in either dosage group had detectable concentrations before seven minutes.

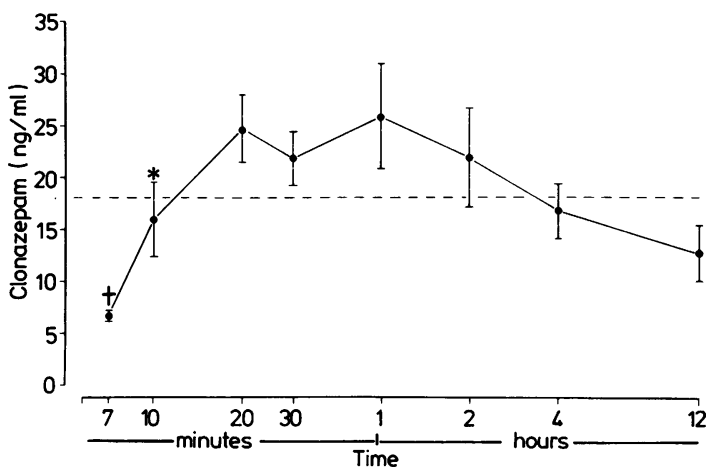

Figure Plasma clonazepam concentrations (mean (SE)) in five children after rectal administration of $0.1 \mathrm{mg} / \mathrm{kg}$ dose (- - =suggested 'therapeutic threshold').

* One high concentration excluded.

tOmission of one sample with undetectable concentration.
The Figure shows the mean (SE) concentration time curve for children given $0 \cdot 1 \mathrm{mg} / \mathrm{kg}$.

All children given $0 \cdot 1 \mathrm{mg} / \mathrm{kg}$ became drowsy, fell asleep within 20 minutes, and remained so for over three hours. Three (cases 8, 10, and 11) remained ataxic and incoordinated at four hours.

\section{Discussion}

Peak concentrations between 10 minutes and two hours after rectal administration of solution suggest that clonazepam is rapidly absorbed from the rectum. These concentrations occurred slightly later, however, than those reported for diazepam in children. ${ }^{10} 11$ Peak concentration times after intravenous injection have not been reported in children of this age, but it must be assumed that the peaks after rectal administration occur later.

Blood concentrations of clonazepam necessary to stop continuing convulsions are not known. Ståhl et al reported that epileptogenic discharges on electroencephalogram were noticeably reduced or abolished for varying periods in four children given clonazepam intravenously; peak concentrations at these times ranged from 7 to $11 \mathrm{ng} / \mathrm{ml}^{12}$ Congdon and Forsythe found no recurrence of convulsions in children with concentrations above $17.7 \mathrm{ng} / \mathrm{ml} .{ }^{6}$ In adults clonazepam concentrations up to $36 \cdot 8 \mathrm{ng} / \mathrm{ml}$ were obtained in volunteers given $2 \mathrm{mg}$ intravenously. This dose is twice that which usually stops convulsions in this age group. A therapeutic concentration threshold of $18 \mathrm{mg} / \mathrm{ml}$ might therefore be suggested, although this may be higher than necessary and subject to wide interindividual variation. No child given $0.05 \mathrm{mg} / \mathrm{kg}$ achieved this concentration, but the value was exceeded within 20 minutes in all children given the higher dose. Slightly lower concentrations achieved by all children within 10 minutes may well be effective.

None of the children in this study showed signs of respiratory depression. This has been reported considerably more often after the use of diazepam intravenously, although this may reflect the more common use of this drug. Other adverse effects did occur, however, in all children in the higher dosage group. They had muscular incoordination, ataxia, and sleepiness with onset within 20 minutes of administration and a duration of at least three hours. The three patients who remained ataxic at four hours were not so one hour later, although all remained drowsy. Although these effects occurred when plasma concentrations were highest and were only present when concentrations exceeded 18 $\mathrm{ng} / \mathrm{ml}$, except in case 11 who was not ataxic with a concentration of $20 \cdot 2 \mathrm{ng} / \mathrm{ml}$ at 12 hours, there may be no clear relation between such adverse effects 
and drug concentrations. Similar concentrations produced such effects in only half the children in the series reported by Dreifuss et al. ${ }^{13}$ Whether the incidence of such effects after the use of clonazepam to stop convulsions represents a major disadvantage is not clear.

If clonazepam is the drug of choice for continuing convulsions $^{14}$ then the facility for a convenient and rapidly effective therapeutic approach offered by rectal administration would be as important for clonazepam as has been shown to be the case in practice for diazepam. These results suggest that a dose of $0 \cdot 1 \mathrm{mg} / \mathrm{kg}$ clonazepam administered rectally to young children may be expected to produce a rapidly effective anticonvulsant effect. Further work is necessary to confirm its rapid absorption, its usefulness as an effective treatment, and to develop convenient means of administration along lines presently offered by the availability of rectal tubes containing diazepam (Stesolid).

R E Cullen is a research nurse supported by a grant from the Birmingham Children's Hospital Centenary Research Fund. We thank Roche Products Limited for undertaking the drug assays.

\section{References}

${ }^{1}$ Bower B. The treatment of epilepsy in children. Br J Hosp Med 1978;19:8-19.

${ }^{2}$ Rutter N, Metcalfe DH. Febrile convulsions-what do parents do? Br Med J 1978;ii:1345-6.

${ }^{3}$ Ferngren $\mathrm{H}$. Diazepam treatment for acute convulsions in children. Epilepsia 1974;15:27-37.
${ }^{4}$ Bamberger P, Matthes A. Eine neue therapiemöglichkeit der status epilepticus im kindersalter mit valium IV. Zeitschrift für Kinderheilkunde 1966;95:155-63.

${ }^{5}$ Pinder RM, Brogden RN, Speight TM, Avery GS. Clonazepam: a review of its pharmacological properties and therapeutic efficacy in epilepsy. Drugs 1976;12:321-61.

6 Congdon PJ, Forsythe WI. Intravenous clonazepam in the treatment of status epilepticus in children. Epilepsia 1980;21: 97-102.

7 Jensen PK, Abild K, Poulsen MN. Serum concentration of clonazepam after rectal administration. Acta Neurol Scand 1983;68:417-20.

${ }^{8}$ de Silva JAF, Bekersley I. Determination of clonazepam and flunitrazepam in blood by electron capture gas-liquid chromatography. J Chromatogr 1974;99:447-60.

9 de Boer AG, Röst-Kaiser J, Bracht H, Breimer DD. Assay of underivatised nitrazepam and clonazepam in plasma by capillary gas chromatography applied to pharmacokinetic and bioavailability studies in humans. $J$ Chromatogr 1978;145: 105-14.

${ }^{10}$ Agurell S, Berlin A, Ferngren H, Hellstrom B. Plasma levels of diazepam after parenteral and rectal administration in children. Epilepsia 1975;16:277-83.

11 Knudsen FU. Plasma diazepam in infants after rectal administration in solution and suppository. Acta Paediatr Scand 1977;66:563-7.

12 Ståhl Y, Persson A, Petters I, Rane A, Theorell K, Walson P. Kinetics of clonazepam in relation to encephalographic and clinical effects. Epilepsia 1983;24:225-31.

${ }^{13}$ Dreifuss FE, Penry JK, Rose SW, Kupferberg HJ, Dyken P, Sato S. Serum clonazepam concentrations in children with absence seizures. Neurology 1975;25:255-8.

14 Bladin PF. The use of clonazepam as an anticonvulsant-clinical evaluation. Med J Aust 1973;1:683-8.

Correspondence to Dr G W Rylance, Children's Hospital, Ladywood Middleway, Birmingham B16 8ET.

Received 28 October 1985 